\title{
STUDIES ON LUMINESCENCE. ATTRACTION OF ANIMALS TO A WEAK LIGHT
}

\author{
By J. A. C. Nicol \\ The Plymouth Laboratory
}

(Text-fig. I)

In order to evaluate the biological significance of luminescence, it is desirable to know how weak light affects the behaviour of marine animals, and what intensities they can see. Much information is available concerning the attractive power of bright lights, and light directed movements (see Verheijen, 1958, for example), but little for weak point sources. Weak coloured lights have been used by Baylor \& Smith (1953) to trap freshwater arthropods.

In the present study, the reaction was tested of animals to a small light-lure, having the colour and intensity of animal luminescence. The light-lure was a conical light-guide, consisting of frosted glass $20 \mathrm{~mm}$ long, $4.4 \mathrm{~mm}$ in diameter at the base, and tapering to a point (Fig. I). The light-lure was mounted in a light-proof case, containing a small light-bulb. A blue filter was placed between the bulb and the base of the light guide. The light which was emitted by the light-lure had a spectral range of $420-540 \mathrm{~m} \mu$, and maximal emission at $475 \mathrm{~m} \mu$. Intensities used were judged by eye to be equivalent to those observed in various marine animals, such as deep-sea fish with luminous barbels and deep-sea shrimp with photophores.

Animals were tested in a black tray, $5 \mathrm{I} \times 4 \mathrm{I} \times \mathrm{IO} \mathrm{cm}$ (Fig. I). This was divided into three compartments, left $(L)$, centre $(C)$ and right $(R)$, separated from each other by clear plastic ('Perspex') partitions. The latter were $>$ shaped, the apex pointing away from $C$ to $L$ or $R$. At the apex was a vertical slit, variable in width $(\mathrm{I}-3 \mathrm{~cm})$, through which the animals could pass at will from the centre to the lateral compartments. The light-lure was hung vertically in one of the lateral compartments, $10 \mathrm{~cm}$ from a vertical slit. The tray was filled with sea water.

An experiment or test was carried out as follows. A batch of animals was dark-adapted for I h, following which they were placed in $C$ and left in the dark for $\mathrm{I}-5 \mathrm{~h}$. Then the numbers of animals in the three compartments were counted. If the animals remained in $C$ or distributed themselves equally among the $L, C$ and $R$, it was concluded that they were not attracted by the light. If they tended to congregate in the lateral compartment containing the light, they were considered to be attracted by the latter. 
Animals tried were small free-swimming crustacea and fish, easily obtained in inshore waters. The light intensity was varied with a rheostat.

Animals attracted by the light (protocols in Appendix I) were: a decapod crustacean Palaemonetes varians, a mysid Praunus neglectus, and a copepod Tigriopus fulvus. Two other decapods Crangon vulgaris and Pandalina brevirostris were probably also attracted. Under the conditions of the experiment a decapod Palaemon serratus and a fish Gobius flavescens were not.

Praunus neglectus gave a clear-cut response, and was employed to determine the minimal intensity of the source to which the animals would respond

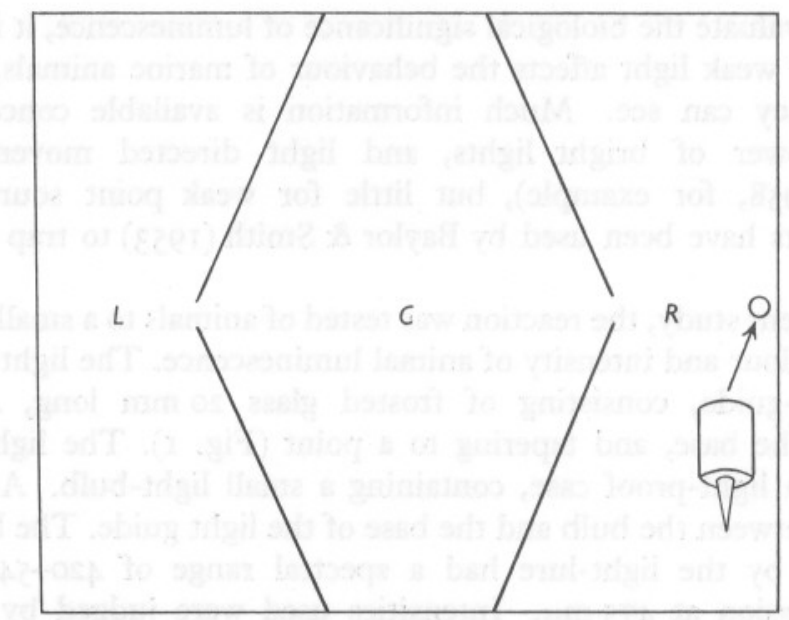

Fig. I. Test-tray and light-guide in its holder (details in text).

(see Appendix 2 for protocols). This was $28.7 \times \mathrm{IO}^{-6} \mu \mathrm{W} / \mathrm{cm}^{2}$ receptor surface at $10 \mathrm{~cm}$ distance. Therefore, the animal responds to a flux of $29 \times 10^{-6} \mu \mathrm{W}$ falling upon a flat surface of $\mathrm{I} \mathrm{cm}$ square in the plane of its eye and at right angles to a line extending from the light-lure to the eye. In the dark-adapted state the eyes lighten, owing to withdrawal of iris-pigments ('superposition' condition). Let us assume that the eye of $P$. neglectus, diameter $0.68 \mathrm{~mm}$, has an effective area of $0.36 \mathrm{~mm}^{2}$ for incident light from a point-source. This is the area of a flat plane in the maximal diameter of the eye at right angles to the axis of the light-beam. Then, $P$. neglectus responds to $10.5 \times 10^{-8} \mu \mathrm{W}$ falling into each eye.

It is not clear what should be regarded as the effective area of the darkadapted ('superposition') compound eye of a malacostracan. The visual area involved is certainly less than the value just presented, since only a fraction of the ommatidia are affected by a directional light. In the superposition eye of Lampyris, some thirty neighbouring ommatidia may concentrate light from a point source upon a single rhabdome (Exner, in Wigglesworth, 1939). 
Pirenne \& Marriott (1955) have determined that a freshwater planarian, Dendrocoelum lacteum, responds to a radiant flux of $15 \times 10^{-9} \mathrm{erg} / \mathrm{sec}$ falling into one eye of diameter $0.08 \mathrm{~mm}$ (i.e. $\mathrm{I} \cdot 5 \times 1 \mathrm{IO}^{-9} \mu \mathrm{W} /$ eye). Values for radiant fluxes of animal-luminescences range from about $\mathrm{I} \times \mathrm{IO}^{-5} \mu \mathrm{W} / \mathrm{cm}^{2}$ at $\mathrm{I} \mathrm{cm}$ for a single radiolarian cell to $4 \times \mathrm{IO}^{-1} \mu \mathrm{W} / \mathrm{cm}^{2}$ at $\mathrm{I} \mathrm{cm}$ for Pyrosoma (Nicol, I958).

\section{SUMMARY}

The attraction for animals of a small light-lure, emitting a feeble blue light, was tested in a multiple choice apparatus. Palaemonetes varians, Praunus neglectus and Tigriopus fulvus were attracted. The minimal intensity to which $P$. neglectus responded was $29 \times 10^{-6} \mu \mathrm{W} / \mathrm{cm}^{2}$ receptor surface.

\section{REFERENCES}

BAYLoR, E. R. \& SMith, F. E., 1953. A physiological light trap. Ecology, Vol. 34, pp. 223-5.

Nicol, J. A. C., I958. Observations on luminescence in pelagic animals. F. mar. biol. Ass. U.K., Vol. 37, pp. 705-52.

Pirenne, M. H. \& MARRIOTt, F. H. C., I955. Light sensitivity of the aquatic flatworm Dendrocoelum lacteum. Nature, Lond., Vol. 175, p. 642.

VERHEIJEN, F. J., 1958. The mechanisms of the trapping effect of artificial light sources upon animals. Arch. néerl. Zool., Vol. 13, pp. I-107.

Wigglesworth, V. B., 1939. The Principles of Insect Physiology. London: Methuen.

\section{APPENDIX}

(I) Test of animals with the light-lure

\begin{tabular}{|c|c|c|c|c|}
\hline \multirow[b]{2}{*}{ Animal } & \multirow{2}{*}{$\begin{array}{l}\begin{array}{c}\text { Duration } \\
\text { of } \\
\text { experiment } \\
\text { (h) }\end{array}\end{array}$} & \multicolumn{3}{|c|}{ Numbers in compartments } \\
\hline & & $L$ & $C$ & $R$ \\
\hline Palaemonetes varians & I & I & 3 & $I^{\star}$ \\
\hline$P$. varians & I & 2 & 0 & $13^{\star}$ \\
\hline Palaemon serratus & I & 5 & 3 & $7^{\star}$ \\
\hline Pandalina brevirostris & 5 & $6 \star$ & 9 & I \\
\hline Praunus neglectus & I & I & 7 & $7^{\star}$ \\
\hline P. neglectus & $2 \frac{1}{2}$ & 3 & 2 & $\mathrm{II}^{\star}$ \\
\hline Tigriopus fulvus & I & 3 & I6 & $30^{\star}$ \\
\hline Gobius ruthensparri & I & I & I3 & o* \\
\hline
\end{tabular}

(2) Response of Praunus neglectus to various light intensities (test lasted 5 h)

\begin{tabular}{cccc} 
Intensity of source & \multicolumn{4}{c}{ Numbers in compartments } \\
\cline { 2 - 3 }$/ \mathrm{cm}^{2}$ at IO $\mathrm{cm}$ & $L$ & $C$ & $R$ \\
$23 \times 10^{-6}$ & 7 & 2 & $7^{\star}$ \\
$77 \cdot 5 \times 10^{-6}$ & $\mathrm{I}$ & 3 & $15^{\star}$ \\
$48 \cdot 8 \times 10^{-6}$ & 3 & 5 & $\mathrm{I}^{\star}$ \\
$36 \cdot 2 \times 10^{-6}$ & 9 & 2 & $\mathrm{I}^{\star}$ \\
$3 \mathrm{I} \cdot 6 \times 10^{-6}$ & 7 & 3 & $\mathrm{I}^{\star}$ \\
$28 \cdot 7 \times 10^{-6}$ & 6 & $\mathrm{I}$ & $\mathrm{II}^{\star}$ \\
$23 \times 10^{-6}$ & 8 & $\mathrm{I}$ & $9^{\star}$ \\
$\star$ & Light-lure in this compartment.
\end{tabular}

